Int Journal of Health Manag. And Tourism 2021

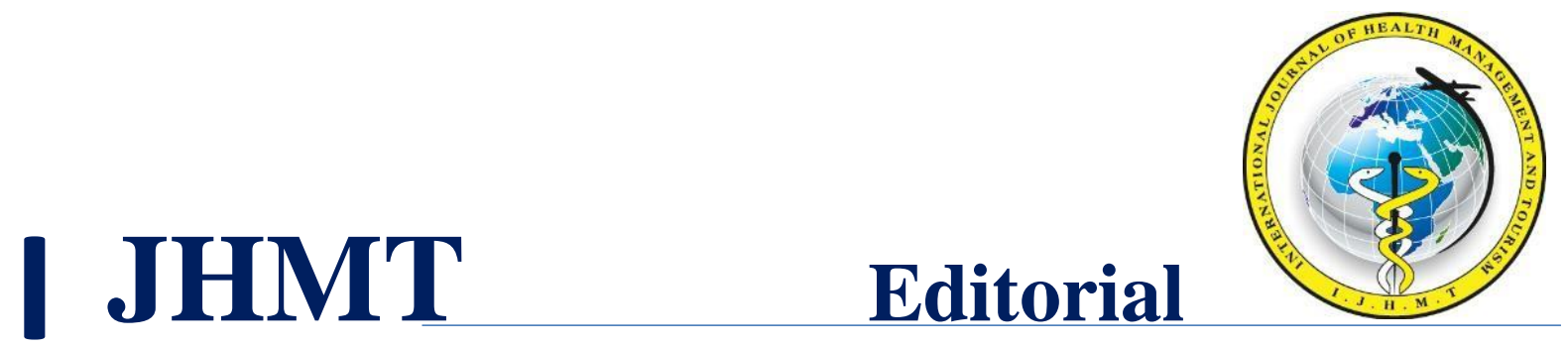

International Journal of Health Management and Tourism

\title{
PLANNED BEHAVIOR THEORY: A STUDY ON HEALTHCARE PROFESSIONALS' BEHAVIOR OF DONATING BLOOD
}

\author{
Sezer KORKMAZ*, Kenan BİRSEN ${ }^{* *}$, Yasemin KURUMLU*** ,G. Gülcan ŞEREMET****, \\ Nesrin KAHRAMAN*****, Ferhat IKBALI AFŞAR****** \\ * Prof. Dr., Ankara Hacı Bayram Veli University, Turkey \\ ORCID Number: 0000-0001-9393-5136 \\ sezer.korkmaz@hbv.edu.tr/ \\ ** Hospital Assisrant Manager, Gazi University, Turkey \\ ORCID Number: 0000-0001-5571-0470 \\ kenanbirsen@gazi.edu.tr \\ ***Expert Nurse, Ankara Dışkapı Yıldırım Beyazıt Training and Research Hospital, Turkey \\ ORCID Number: 0000-0001-8569-2285 \\ yaskur@hotmail.com \\ **** Research Assistant, Çankırı Karatekin University, Turkey \\ ORCID Number: 000-0002-5790-2780 \\ gulcansisman09@gmail.com
}

***** Dental Prodthesis technician, Ankara Topraklık Dental Health Center, Turkey

ORCID Number: 0000-0002-6652-9754

nesrinkahraman06@gmail.com

******Dr., University of Health Sciences 29 May State Hospital, Turkey

ORCID Number: 0000-0002-3813-1087

drfiafsar@gmail.com

Received: 3.07 .2021

Accepted: 26.07.2021

Research Article

\section{Abstract}

Aim: Healthy individuals are the only sources of blood product supply. However, inequality between voluntary donations and blood product requirement is a global problem. The need for 
blood is an important concern for the society as a whole. Volunteer blood donors are the most important factor of safety blood donation. The aim of the study is to determine the level of cognitive perception of healthcare professionals in order to encourage blood donation.

Methods: Accordingly, the intention of health care professionals, who are considered as role models, towards voluntary blood donation has been investigated according to Theory of Planned Behavior This cross-sectional study was carried out in 233 healthcare professionals who were the employees of a tertiary education research hospital in Ankara.

Findings: The participants' intention towards voluntary blood donation is substantially positive $(\overline{\mathrm{X}}=4.41)$. Chronic diseases and previous experiences have significant impact on intention $(p=.01)$. Perceived behavioral control $(\beta=0.407)$ is the strongest variable that predicts the intention.

Conclusion: The study scale has explained the $41 \%$ of overall intention-related variances. It is expected that the positive intentions of the participants towards voluntary blood donation will affect the behavior of the public in this regard positively.

Keywords: Theory of Planned Behavior, Voluntary Blood Donation, Healthcare Professionals, Behavior, Health Management

\section{Introduction}

The availability of safe and adequate blood and blood components is critical for the treatment of many patients (WHO, 2019). Today, despite all the developments in medicine and technology, an alternative treatment tool has not been found that can replace blood, blood components and products obtained from blood. For this reason, blood services are carried out systematically in the world. Donation blood banking as one of these services; includes voluntary, regular, conscious, without expecting anything in return; collecting blood voluntarily, performing the necessary laboratory procedures on the collected blood, storing the blood and delivering it to hospitals (Hablemitoğlu, Özkan, Yıldırım, 2010). Services covering the use of blood for patients and the follow-up of the information recorded after use are provided under the name of transfusion blood banking. Transfusion of blood is an important form of therapy in medicine. Without blood donation there cannot be transfusion of blood. A well-functioning blood transfusion service is dependent on forthcoming blood donors who are willing to donate voluntarily without being mandated (Sandborg, 2000). The blood transfusion services (BTS) in the study area are dependent 
on hospital blood banks that are responsible for blood supplies and blood testing. The primary sources of donated blood are direct donation (mainly patients' relatives), voluntary nonremunerated donors, and mobile blood drives (Amar, Yahia, 2020). Maintaining blood supply is essential because blood transfusions are lifesaving in many situations.

Blood and blood components are continuously needed during especially the pandemic for patients with blood diseases, cancers, trauma, and emergency surgeries. Without proper management of blood supply and demand, hospitals will face a shortage of blood, with the result that many patients may die or suffer unnecessarily.

Desire for improving duration and quality of life connects pertaining to human all ideas to health care services. The enormous advancements achieved in medical technology within the last two decades as well support this philosophy; in particular, highlighting that health care service is a global right, efforts made to increase the rate of access to health care services and implementation of modern operational procedures more intensively are the evidences. However, efforts made to improve health status can increase the need for blood donation indirectly (Maratidou et. al, 2007). Moreover, the only source of supply of blood products is healthy individuals. Therefore, global health organizations recommend establishing the highest standard possible for voluntary blood donors (Canturk et. al, 2013).

Behavioral intentions towards voluntary blood donation can be attributed to the populations' level of social awareness and development. Official data indicate that nearly $5 \%$ of overall population in the developed countries voluntarily donates blood (WHO, 2018). In Turkey, nearly $2 \%$ of overall population voluntarily donates blood (Kizilay, 2017). Although the rates vary among countries, the balance between requirement for blood products and voluntary donations is a global problem. The specific barriers that would restrain potential volunteers of blood donation from transforming their intention into behavior include prejudices, incomplete information, incorrect religious rituals, and social pressure (Cevizci et. al, 2010).

Theory of Planned Behavior (TPB) which enables anticipation of intention and behavior towards a particular situation, was propounded in 1985 by Icek Ajzen (Akinci and Kiymalioglu, 2015). The theory is based on the hypothesis that the individuals act usually reasonably and, before exhibiting a behavior, they indirectly or clearly evaluate the effects of that behavior (Fishbein and Ajzen, 2010). The most critical determinant of behavior is the intention. According to the TPB, intention is directed by three main variables; attitude, subjective norm, and perceived behavioral 
control (Lawson, 2010). Attitude is characteristically a rater (beautiful - not beautiful) in nature and leads the individual to a specific target (Fishbein and Ajzen, 2010). Subjective norm is the effort made to harmonize the individual's intention towards behavior with the intentions of the others, who are important to the individual (Ajzen, 2005). Nevertheless, the actual control of behaviors emerges with the influences of internal and external factors, which Ajzen defines as perceived behavioral control (Fishbein and Ajzen, 2010). Internal factors that influence the performance of a behavior include the knowledge, skills, emotions and the ability possessed, whereas external factors include opportunities and the level of dependence to the others (Akinci and Kiymalioglu, 2015). Finally, the relative burden of these three main variables that drive intention may differ from person to person or from one population to another (Fishbein and Ajzen, 2010). The theoretical model of the TPB is shown in Figure 1.

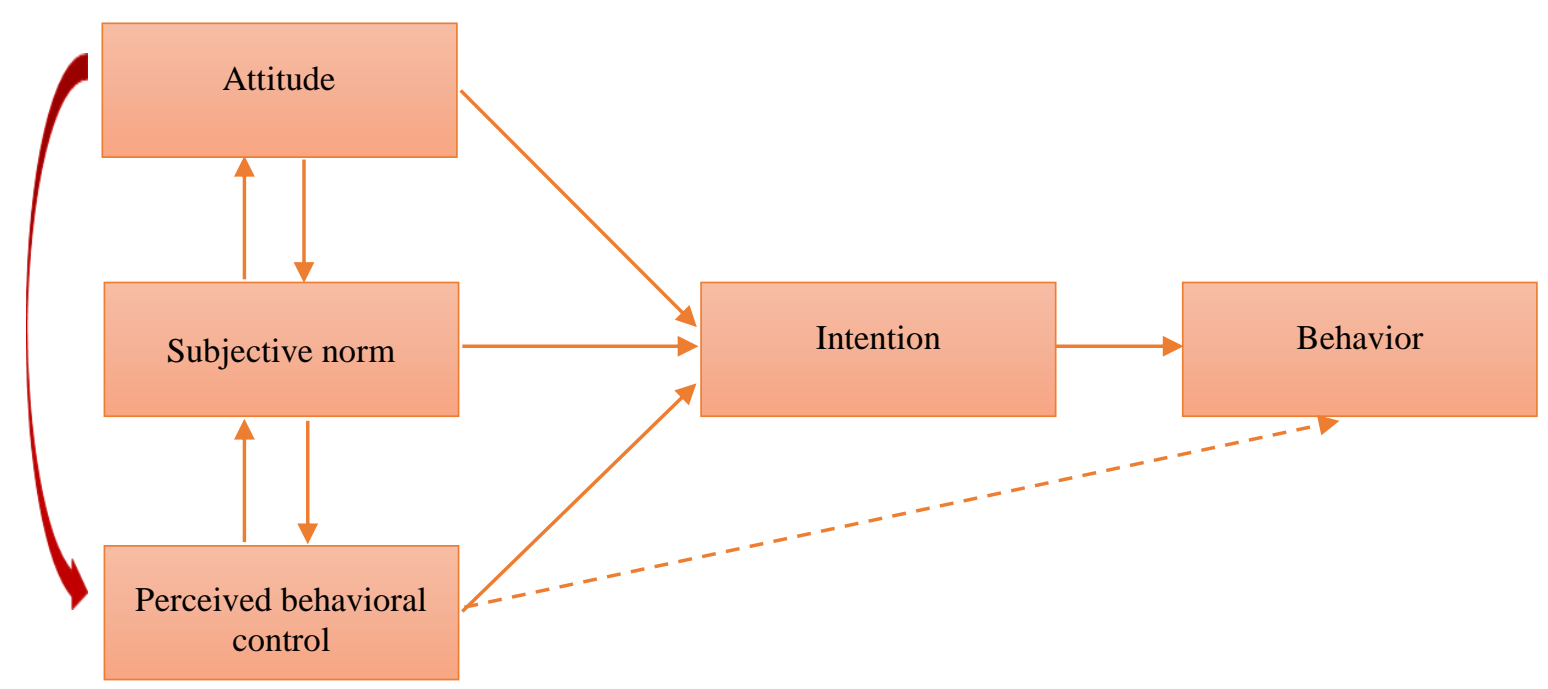

Figure 1. Theoretical model of planned behavior theory

According to the theory of planned behavior, the main determinant of a behavior is intention. The stronger the intention, the more likely the behavior will occur. According to this theory, if the individual thinks that the resources and opportunities required for a behavior lacks, a strong intention regarding that behavior will not occur (Korkmaz, Sertoğlu; 2013). Also, even if the person has an intention, that behavior may not occur if he cannot control his individual will. Intention is a function of attitude towards behavior, subjective norms, and perceived behavioral 
control. Attitude towards behavior reflects the positive or negative general evaluations of the individual towards realizing the behavior. Subjective norms are the social pressure that a person perceives to perform or not perform the behavior in question. In other words, it is a reflection of the individual's perception towards what other people want him to do (Akıncı \& Kıymalığlu, 2014). Perceived behavioral control refers to the individual's perception of his ability or sufficiency to perform the behavior in question.

There are two important points to note in the basic model presented in Figure 1 (Ajzen 2005). The first of these is that perceived behavioral control has an effect on the individual's motivation to perform the behavior on intention. The second important issue is the direct relationship between perceived behavioral control and behavior. The performance of a behavior depends not only on motivation, but also on control towards that behavior. Therefore, perceived behavioral control can determine behavior regardless of the intention to perform the behavior.

The most important reason for using the theory of planned behavior in this study is that it contributes to the development of behavior, behavioral intention and the information process, and shows a systematic approach to to defining, measuring and conceptualizing determinants (Montano et al., 1997). In this direction, the research part of the study was designed based on the above model.

In this context, the attitude in the model describes the attitudes of health workers towards blood donation. Towards the blood donation of the healthcare professionals; the thoughts of the people who are important to healthcare professionals and a reflection of the perception of the behavior they want the person to show refers the subjective norm. Perceived behavioral control is what healthcare professionals think about themselves if they donate blood.

The perception of control towards realizing the behavior should be created in a way that is close to reality. For this reason, it is necessary to ensure the continuity of perception and involvement in blood donation for the motivation that will transform the positive attitude of healthcare professionals towards blood donation into behavior. 


\section{Research Methodology}

This study was carried out in a tertiary hospital in Ankara. The data in the study were collected using the convenience sampling method. Within the scope of this study, 233 of a total of 865 health care professionals (254 doctors and 611 nurses) working in the relevant hospital could be reached. However, $29(10.3 \%)$ of these 281 health care professionals declared they have not enough time to participate in the study, whereas $19(6.8 \%)$ were excluded from the analysis as their answers were not suitable for statistical analysis. The remaining participants $(n=233)$ represented the population eligible for this study.

Data from this study was collected via a questionnaire consisting of two sections. The items in the first section were retrieved from the questionnaire prepared and implemented according to the principles of TPB in an early study (Argan, 2016). However, as the target population was different in the present study, some of the items were revised, and then a pre-survey was performed. After revision, the number of items in the first section of the questionnaire was 28 , of which 26 were the items representing the main variables that direct the intention and the intention itself and were evaluated by 5-item Likert-type scale. The remaining two were close-ended questions to be answered as Yes or No; "Do you have a chronic illness?" and "Have you ever donated blood before?" In the second section of the questionnaire, gender, marital status, age, education level and monthly income were inquired to assess the socio-demographic characteristics of the participants.

The study was approved by the top executives of relevant hospital. Moreover, according to the international principals of ethics, all of the participants were reassured that their personal information will be kept confidential and that the study data will be used for scientific purpose only. Each interview, including the participants' questions and comments about the research, was lasted almost twenty minutes.

The data obtained in this study were analyzed using SPSS package. It was conducted exploratory factor analysis after the validity and reliability analysis of the scale. This study parametric tests were performed because the data were distributed normally. Multiple regression and correlation analyses were used to measure the predictive power of the variables and the relationship between 
them the demographic profile of participants were analyzed with $t$-test and ANOVA test. Finally, $\mathrm{p}$ value of $<.05$ was considered statistically significant.

This research; This is an empirical study that explains the behavioral intentions of healthcare profesionals towards blood donation within the framework of PDT principles. In this context, based on the conceptual model of PDT shown in Figure 1, the main hypothesis of the research is "H1: Attitude, subjective norm and perceived behavioral control affect the intention of healthcare profesionals to donate blood." sentence. The sub-hypotheses within the scope of the basic hypothesis of the study are as follows:

$\mathrm{H} 1 \mathrm{a}=$ The opinions of healthcare professionals about donating blood differ significantly according to socio-demographic characteristics.

$\mathrm{H} 1 \mathrm{~b}=$ The status of healthcare professionals with a chronic disease affects their attitude towards donating blood.

H1c: Previous blood donation status of healthcare workers affects their perspective towards donating blood.

H1d: There is a relationship between healthcare professionals' attitude towards blood donation, subjective norm, perceived behavioral control and their intentions.

\section{Analysis}

The findings regarding the statistical analysis of the study data are listed below in tables. Sociodemographic characteristics of the participants are shown in Table 1.

Table 1. Socio-demographic characteristics of the participants

\begin{tabular}{|c|c|c|c|}
\hline \multicolumn{4}{|l|}{ Gender } \\
\hline & Female & 133 & 57.1 \\
\hline & Male & 100 & 42.9 \\
\hline \multicolumn{4}{|l|}{ Age } \\
\hline & $18-29$ & 35 & 15.0 \\
\hline & $30-39$ & 123 & 52.8 \\
\hline & $>40$ & 75 & 32.2 \\
\hline \multicolumn{4}{|c|}{ Marital status } \\
\hline & Single & 52 & 22.3 \\
\hline & Married & 181 & 77.7 \\
\hline \multicolumn{4}{|c|}{ Educational status } \\
\hline & Associate degree & 53 & 22.7 \\
\hline & Bachelor's & 151 & 64.8 \\
\hline
\end{tabular}


(Table 1 cont.)

$\begin{array}{ll}\text { Postgraduate } & 29\end{array}$

12.5

Income status

$$
\begin{gathered}
520-695 \$ \\
696-870 \$ \\
>871 \$
\end{gathered}
$$

Dou you have a chronic illness?

$\begin{array}{lll}\text { Yes } & 56 & 24.0\end{array}$

$\begin{array}{lll}\text { No } & 177 & 76.0\end{array}$

Have you ever donated blood before?

Total

As shown in table 1, participants in this study $57.1 \%$ were female and, $67.8 \%$ were under of age 40. 77.7 's $\%$ of the participants stated that they were married while $77.3 \%$ stated that they had bachelor's and postgraduate levels of education. The overwhelming majority of participants income less than $\$ 871$ per month (86.3\%). In addition to this, $75.9 \%$ of the participants stated that they did not have a chronic disease and $67.8 \%$ had previously experienced voluntary blood

\begin{tabular}{|c|c|c|c|}
\hline Factors & KMO test & Barlett's test & Sig. \\
\hline Attitude & .797 & 370.898 & $.0001 *$ \\
\hline Subjective norm & .810 & 471.239 & $.0002 *$ \\
\hline Perceived behavioral control & .823 & 625.649 & $.0001 *$ \\
\hline Niyet & .758 & 383.140 & $.0001 *$ \\
\hline
\end{tabular}
donation.

Table 2. Validity analysis results

Field (2009) stated that in order to test the suitability of the scale to "Factor Analysis", the value of $\mathrm{KMO}$ test must be greater than .50. In the validity analysis, as shown in table 2, the KMO values were distributed between .758 and .823 and the scale met the requirements for "Factor Analysis". 
Table 3. Reliability analysis results

\begin{tabular}{|c|c|c|}
\hline Factors & Number of item & Cronbach's Alpha $(\alpha)$ \\
\hline Attitude & 5 & .793 \\
\hline Subjective norm & 6 & .796 \\
\hline Perceived behavioral control & 8 & .820 \\
\hline Intention & 5 & .784 \\
\hline Total of scale & 24 & .911 \\
\hline
\end{tabular}

Murphy and Davidshofer (2015) stated that "Cronbach's Alpha" value should be above .60 for the scale to have sufficient security. In the reliability analysis, as shown in table 3 , the Cronbach alpha value of all factors $>.60$ and the scale was reliable.

Table 4. Mean and standard deviation values results

\begin{tabular}{|c|c|c|c|}
\hline Factors & $\mathrm{n}$ & Mean & Standard dev. \\
\hline Attitude & 233 & 4.53 & .47 \\
\hline Subjective norm & 233 & 4.06 & .65 \\
\hline Perceived behavioral control & 233 & 3.90 & .63 \\
\hline Intention & 233 & 4.41 & .50 \\
\hline
\end{tabular}

Data obtained with scales of five, "Never" if $\overline{\mathrm{X}}=1.00-1.79$, "Rarely" if $\overline{\mathrm{X}}=1.80-2.59$, "Occasionally" if $\bar{X}=2.60-3.39$, "Frequently" if $\bar{X}=3.40-4.19$ and, "Every time" if $\bar{X}=4.20-5.00$, it is interpreted as (Uzun and Yigit, 2011). As shown in table 4, the items under the subjective norm and perceived behavioral control factors were answered "Frequently", and the items under the attitude and intention factors were answered as "Always". 
Table 5. Results of explanatory factor analysis

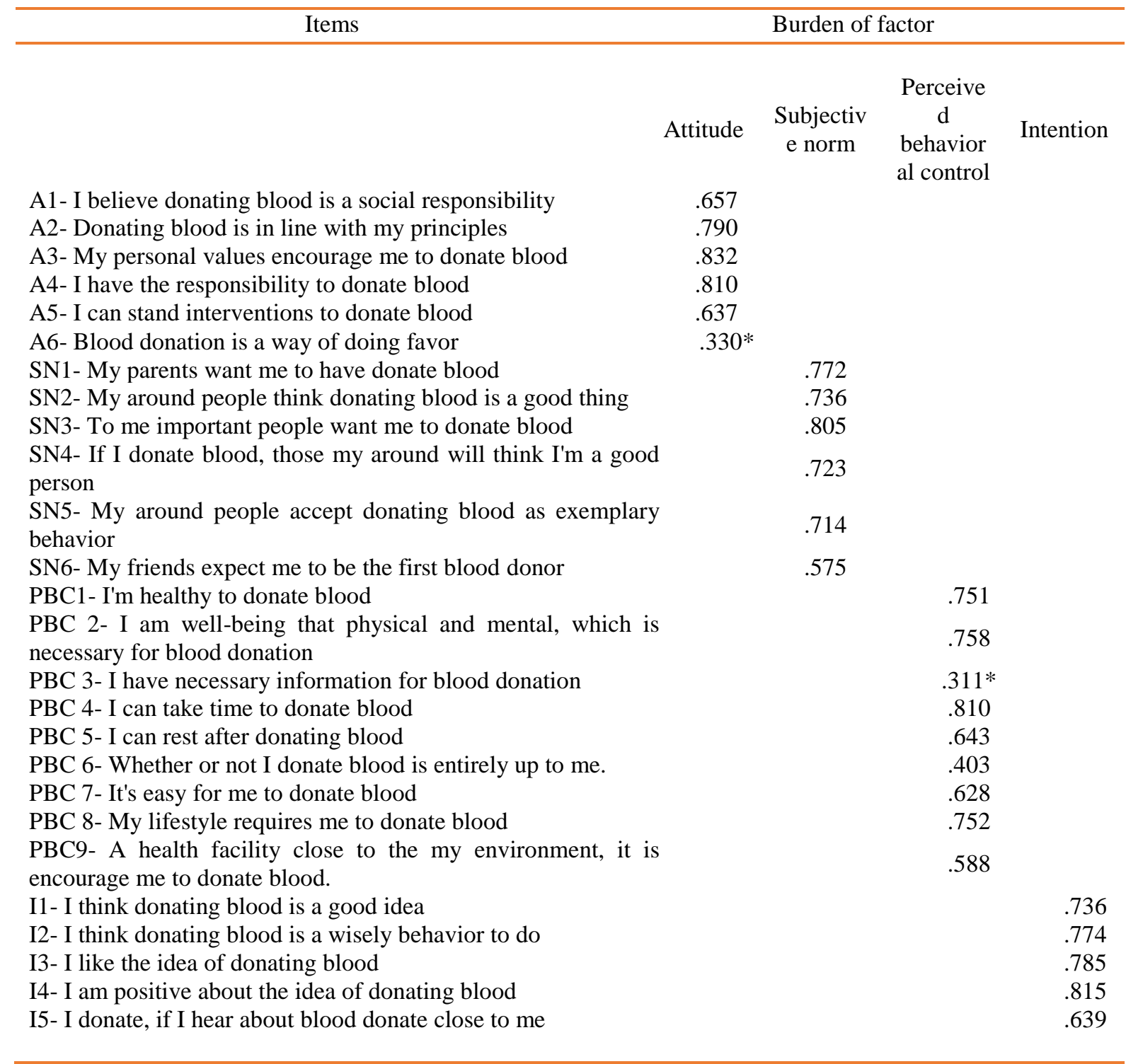

$*$ Burden of factor $<.40$

As a result of explanatory factor analysis; It has been observed that 1, 2, 3, 4, 5 and 19th items were gathered under the variable "Attitude". Also, it has been observed that 6, 7, 8, 9, 10 and 20th items were gathered under the variable "Subjective Norm". In addition to this, the items gathered under the variable "Perceived Behavioral Control" are 11, 12, 13, 14, 15, 16, 17, 18 and 26th. Also, the items gathered under the variable "Intention" are 21, 22, 23, 24 and 25th. Furthermore, 2 items were removed from the scale since their factor burden were lower than 40 (Büyüköztürk, 2010). The first one was" I have necessary information for blood donation" which is the 13th item and 
the other one was "Blood donation is a way of doing favor" which is 19th item. Thus, the number of items in the study scale decreased from 26 to 24 .

Table 6. Gender variable t-Test results

\begin{tabular}{|c|c|c|c|c|c|c|}
\hline & Gender & $\mathrm{n}$ & Mean & Standart dev. & $\mathrm{t}$ & $\mathrm{p}$ \\
\hline \multirow{2}{*}{ Attitude } & Female & 133 & 4.47 & .47 & 2.04 & $.04 *$ \\
\hline & Male & 100 & 4.60 & .48 & 2.03 & $.04 *$ \\
\hline \multirow{2}{*}{ Subjective norm } & Female & 133 & 3.94 & .64 & 3.21 & $.00 *$ \\
\hline & Male & 100 & 4.21 & .63 & 3.23 & $.00 *$ \\
\hline \multirow{2}{*}{ Perceived behavioral control } & Female & 133 & 3.74 & .60 & 4.57 & $.00 *$ \\
\hline & Male & 100 & 4.11 & .62 & 4.55 & $.00 *$ \\
\hline \multirow{2}{*}{ Intention } & Female & 133 & 4.34 & .49 & 2.38 & $.01 *$ \\
\hline & Male & 100 & 4.50 & .50 & 2.38 & $.01 *$ \\
\hline
\end{tabular}

As shown in table 6, the health care professionals' intention to donate blood voluntarily showed significant difference according to gender $(\mathrm{p}<.05)$. In addition, males had higher intention to donate blood voluntarily than females (Male $\overline{\mathrm{X}}>$ Female $\overline{\mathrm{X}}$ ).

Table 7. Age variable ANOVA test results

\begin{tabular}{|c|c|c|c|c|c|c|}
\hline & Age & $n$ & Mean & Standart dev. & $\mathrm{F}$ & $\mathrm{p}$ \\
\hline \multirow{3}{*}{ Attitude } & $18-29$ & 35 & 4.52 & .47 & \multirow{3}{*}{1.393} & \multirow{3}{*}{.25} \\
\hline & $30-39$ & 123 & 4.48 & .48 & & \\
\hline & $\geq 40$ & 75 & 4.60 & .48 & & \\
\hline \multirow{3}{*}{ Subjective norm } & $18-29$ & 35 & 3.83 & .69 & \multirow{3}{*}{3.374} & \multirow{3}{*}{.02} \\
\hline & $30-39$ & 123 & 4.04 & .66 & & \\
\hline & $\geq 40$ & 75 & 4.19 & .60 & & \\
\hline \multirow{3}{*}{$\begin{array}{l}\text { Perceived behavioral } \\
\text { control }\end{array}$} & $18-29$ & 35 & 3.75 & .70 & \multirow{3}{*}{1.816} & \multirow{3}{*}{.17} \\
\hline & $30-39$ & 123 & 3.88 & .59 & & \\
\hline & $\geq 40$ & 75 & 3.99 & .66 & & \\
\hline \multirow{3}{*}{ Intention } & $18-29$ & 35 & 4.40 & .50 & \multirow{3}{*}{0.29} & \multirow{3}{*}{.75} \\
\hline & $30-39$ & 123 & 4.38 & .49 & & \\
\hline & $\geq 40$ & 75 & 4.44 & .52 & & \\
\hline
\end{tabular}


As shown in table 7, the health care professionals' intention to donate blood voluntarily was not significantly different in terms of attitude $(\mathrm{p}=.25)$, perceived behavioral control $(\mathrm{p}=.17)$ and intention $(p=.75)$. Subjective norm was the only variable showing difference between the age groups $(\mathrm{p}=.02)$, and the difference was observed between the subjects aged 18-29 year-old and those at and over the age of 40 years $(\mathrm{p}=.00)$. Furthermore, those at and over the age of 40 years had higher intention to donate blood voluntarily as compared to the other age groups ( $\geq 40$-yearold $\overline{\mathrm{X}}>$ Other age groups $\overline{\mathrm{X}}$ ).

Table 8. Marital status variable t-Test results

\begin{tabular}{lcccccc}
\hline & & & & & & \\
\hline & Marital status & $\mathrm{n}$ & Mean & Standart dev. & $\mathrm{t}$ & $\mathrm{p}$ \\
Attitude & Single & 52 & 4.42 & .55 & 1.75 & .08 \\
& Married & 181 & 4.55 & .45 & 1.58 & .11 \\
Subjective norm & Single & 52 & 4.00 & .75 & 0.60 & .54 \\
& Married & 181 & 4.07 & .62 & 0.55 & .59 \\
Perceived behavioral & Single & 52 & 3.88 & .60 & 0.21 & .83 \\
control & Married & 181 & 3.90 & .65 & 0.22 & .82 \\
& & & & & & \\
Intention & Single & 52 & 4.31 & .53 & 1.43 & .15 \\
& Married & 181 & 4.43 & .49 & 1.37 & .17 \\
$* p<.05$ & & & & & &
\end{tabular}

As shown in table 8 , The health care professionals' intention to donate blood voluntarily showed significant indifference according to marital status ( $\mathrm{p}<.05)$. Nevertheless, married had higher intention to donate blood voluntarily than single (Married $\bar{X}>$ Single $\bar{X}$ ).

Table 9. Educational status variable ANOVA test results

\begin{tabular}{|c|c|c|c|c|c|c|}
\hline & Educational status & $\mathrm{n}$ & Mean & Standart dev. & $\mathrm{F}$ & $\mathrm{p}$ \\
\hline \multirow{3}{*}{ Attitude } & Associate degree & 53 & 4.54 & .49 & \multirow{3}{*}{3.83} & \multirow{3}{*}{$.02 *$} \\
\hline & Bachelor's & 151 & 4.57 & .48 & & \\
\hline & Postgraduate & 29 & 4.30 & .42 & & \\
\hline \multirow{3}{*}{ Subjective norm } & Associate degree & 53 & 3.95 & .63 & \multirow{3}{*}{2.57} & \multirow{3}{*}{.08} \\
\hline & Bachelor's & 151 & 4.13 & .65 & & \\
\hline & Postgraduate & 29 & 3.90 & .65 & & \\
\hline
\end{tabular}


(Table 9 cont.)

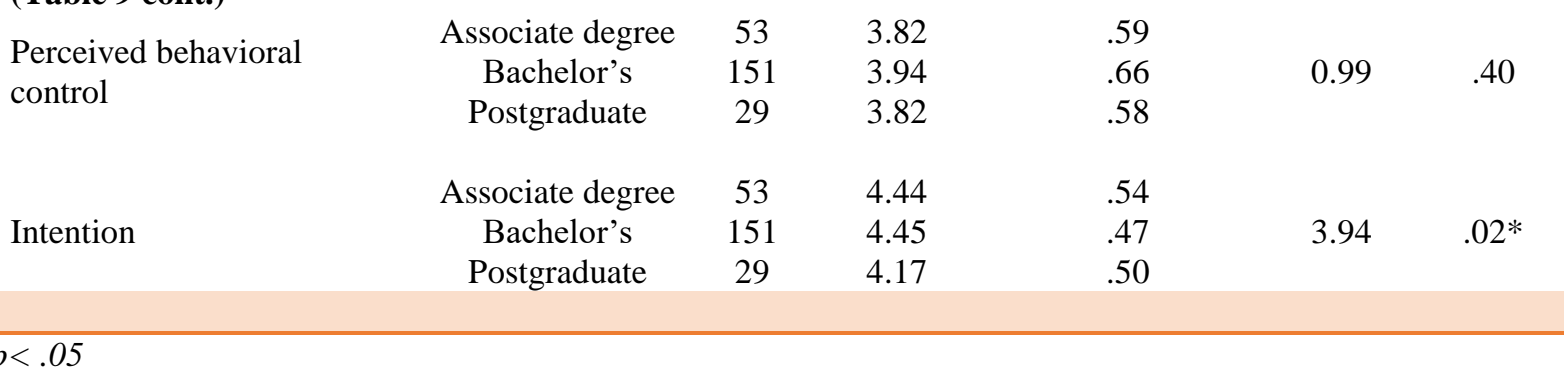

As shown in table 9, the health care professionals' intention to donate blood voluntarily was not significantly different in terms of subjective norm $(\mathrm{p}=.08)$ and perceived behavioral control $(\mathrm{p}=$ $.40)$. The variables that showed difference were the attitude $(\mathrm{p}=.02)$ and intention $(\mathrm{p}=.02)$; the difference was observed between those with associate degree and postgraduate degree $(\mathrm{p}=.01)$ as well as between those with bachelor's degree and postgraduate degree $(p=.00)$ for both variables. Furthermore, those with bachelor's degree had higher intention to donate blood voluntarily as compared to the other levels of education (Bachelor's degree $\overline{\mathrm{X}}>$ Other levels of education $\overline{\mathrm{X}}$ ).

Table 10. Income status variable ANOVA test results

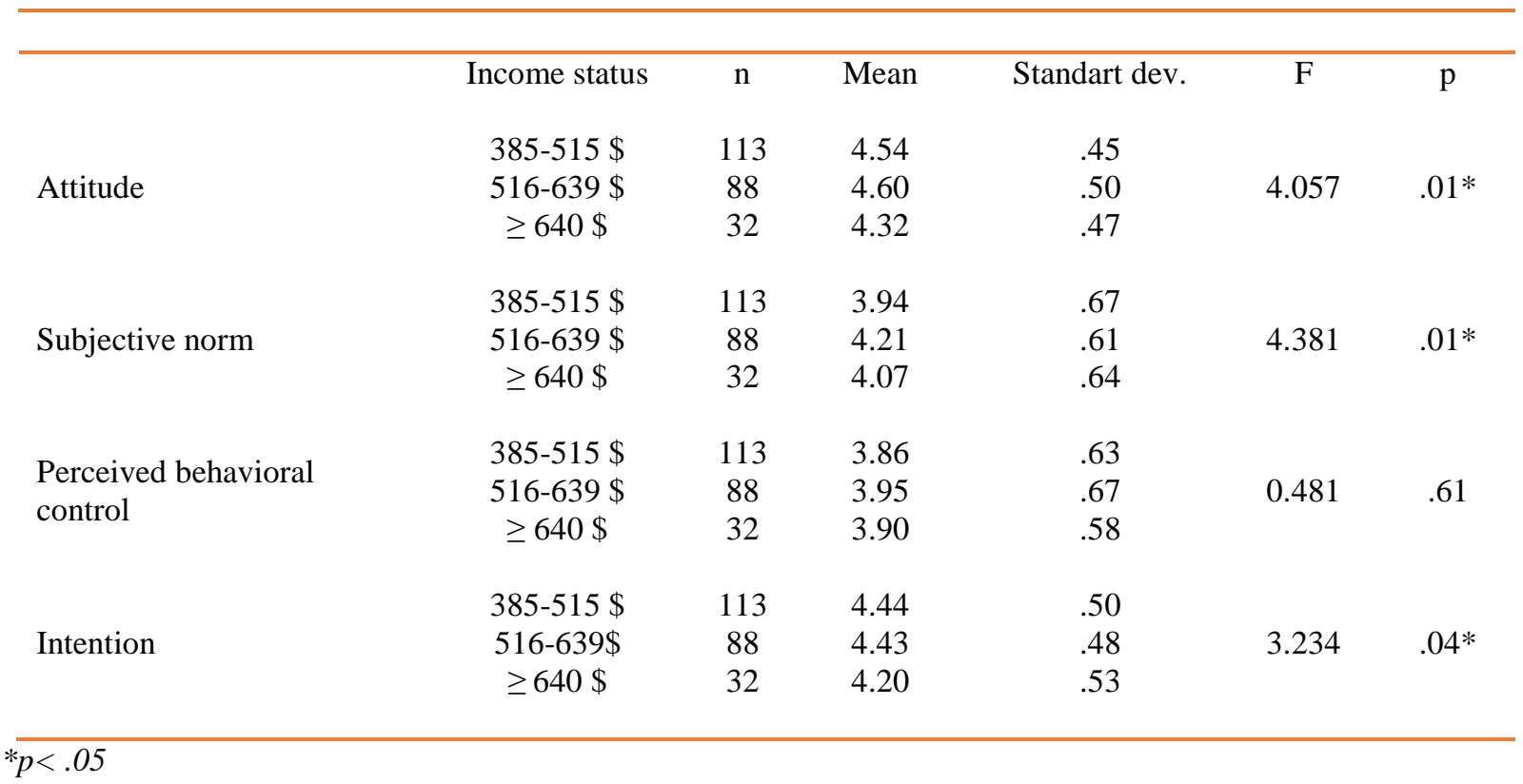

As shown in table 10, the health care professionals' intention to donate blood voluntarily was not significantly difference in terms of perceived behavioral control $(p=.61)$. The variables that showed difference were the attitude $(\mathrm{p}=.01)$, subjective norm $(\mathrm{p}=.01)$ and intention $(\mathrm{p}=.04)$. The 
difference was between those having monthly income of 385-515 $\$$ and more than $640 \$(\mathrm{p}=.02)$ as well as 516-639 $\$$ and more than $640 \$(\mathrm{p}=.00)$ for attitude; 385-515 $\$$ and 516-639 $\$(\mathrm{p}=.00)$ for subjective norm; 385-515 $\$$ and more than $640 \$(\mathrm{p}=.01)$ as well as 516-639 $\$$ and more than $640 \$(\mathrm{p}=.02)$ for intention. Furthermore, intention to donate blood voluntarily was higher in those with monthly income of 516-639 \$ as compared to the others (516-639 \$ $\bar{X}>$ Other groups $\bar{X}$ ).

Table 11. Have a chronic illness variable t-Test results

\begin{tabular}{|c|c|c|c|c|c|c|}
\hline & Chronic illnes & $\mathrm{n}$ & Mean & Standart dev. & $\mathrm{t}$ & $\mathrm{p}$ \\
\hline \multirow{2}{*}{ Attitude } & Yes & 56 & 4.50 & .50 & 0.45 & .65 \\
\hline & No & 177 & 4.53 & .47 & 0.43 & .66 \\
\hline \multirow{2}{*}{ Subjective norm } & Yes & 56 & 4.03 & .67 & 0.25 & .08 \\
\hline & No & 177 & 4.06 & .65 & 0.25 & .80 \\
\hline \multirow{2}{*}{$\begin{array}{l}\text { Perceived behavioral } \\
\text { control }\end{array}$} & Yes & 56 & 3.84 & .69 & 0.75 & .45 \\
\hline & No & 177 & 3.91 & .61 & 0.70 & .48 \\
\hline \multirow{2}{*}{ Intention } & Yes & 56 & 4.24 & .52 & 2.85 & $.01 *$ \\
\hline & No & 177 & 4.46 & .48 & 2.74 & $.01 *$ \\
\hline
\end{tabular}

As shown in table 11, the health care professionals' intention to donate blood voluntarily was significantly difference in terms of only intention $(\mathrm{p}=.01)$. Nevertheless, those without chronic illness had higher intention to donate blood voluntarily (Without chronic illness $\bar{X}>$ With chronic illness $\overline{\mathrm{X}}$ ).

Table 12. Having donated blood before variable t-Test results

\begin{tabular}{|c|c|c|c|c|c|c|}
\hline & $\begin{array}{l}\text { Having donated } \\
\text { blood before }\end{array}$ & $\mathrm{n}$ & Mean & Standart dev. & $\mathrm{t}$ & $\mathrm{p}$ \\
\hline \multirow{2}{*}{ Attitude } & Yes & 158 & 4.57 & .45 & 1.96 & .05 \\
\hline & No & 75 & 4.44 & .53 & 1.84 & .07 \\
\hline \multirow{2}{*}{ Subjective norm } & Yes & 158 & 4.15 & .60 & 3.37 & $.00 *$ \\
\hline & No & 75 & 3.85 & .71 & 3.17 & $.00 *$ \\
\hline
\end{tabular}




\section{(Table 12 cont.)}

Perceived behavioral control

$\begin{array}{lcc}\text { Yes } & 158 & 4.01 \\ \text { No } & 75 & 3.66 \\ & & \\ \text { Yes } & 158 & 4.46 \\ \text { No } & 75 & 4.29\end{array}$

4.01

3.66

4.46

4.29
.58

.68

.47

.53
$4.14 \quad .00 *$

$3.90 \quad .00 *$

$2.52 \quad .01^{*}$

$2.42 \quad .02 *$

$* p<.05$

As shown in table 12, according to having donated blood before, the health care professionals' intention to donate blood voluntarily was not significantly difference in terms of only attitude ( $\mathrm{p}=$ .05). Nevertheless, intention towards voluntary blood donation was higher among those who have experienced blood donation previously (Those who have donated blood before $\overline{\mathrm{X}}>$ Those who have not donated blood before).

Table 13. Multiple regression analysis results

\begin{tabular}{|c|c|c|c|c|c|}
\hline & B & Standard error & $\beta$ & $\mathrm{t}$ & $\mathrm{p}$ \\
\hline Stable & 1.776 & .251 & - & 7.074 & $.000^{*}$ \\
\hline Attitude & 0.198 & .064 & 0.189 & 3.067 & $.002 *$ \\
\hline Subjective Norm & 0.118 & .059 & 0.154 & 1.998 & $.047 *$ \\
\hline Perceived Behavioral Control & 0.322 & .055 & 0.407 & 5.829 & $.000 *$ \\
\hline
\end{tabular}

As shown in table 13, it was a linear and significant relationship between the participants predicting the voluntary blood donation. While the strongest relationship between the variables is between the subjective norm and the perceived behavioral control (.-685), the weakest relationship is between attitude and perceived behavioral control (.-411). The predictive power of the variables is respectively like this; perceived behavioral control $(\beta=0,407)$, attitude $(\beta=0,189)$ and subjective norm $(\beta=0,154)$. 
Table 14. Correlation analysis results

\begin{tabular}{|c|c|c|c|c|c|}
\hline & & Attitude & $\begin{array}{l}\text { Subjective } \\
\text { norm }\end{array}$ & $\begin{array}{c}\text { Perceived } \\
\text { behavior control }\end{array}$ & Intention \\
\hline Attitude & $\begin{array}{c}\text { Pearson } \\
\mathrm{p}\end{array}$ & 1 & $\begin{array}{l}.561- \\
.000^{*}\end{array}$ & $\begin{array}{l}.411- \\
.000^{*}\end{array}$ & $\begin{array}{l}.442- \\
.000^{*}\end{array}$ \\
\hline Subjective norm & $\begin{array}{l}\text { Pearson } \\
\text { p }\end{array}$ & $\begin{array}{l}.561- \\
.000^{*}\end{array}$ & 1 & $\begin{array}{l}.685- \\
.000^{*}\end{array}$ & $\begin{array}{l}.539- \\
.000^{*}\end{array}$ \\
\hline $\begin{array}{l}\text { Perceived behavioral } \\
\text { control }\end{array}$ & $\begin{array}{c}\text { Pearson } \\
\text { p }\end{array}$ & $\begin{array}{l}.411- \\
.000^{*}\end{array}$ & $\begin{array}{l}.685- \\
.000^{*}\end{array}$ & 1 & $\begin{array}{l}.590- \\
.000^{*}\end{array}$ \\
\hline Intention & $\begin{array}{l}\text { Pearson } \\
\mathrm{p}\end{array}$ & $\begin{array}{l}.442- \\
.000^{*}\end{array}$ & $\begin{array}{l}.539- \\
.000 *\end{array}$ & $\begin{array}{l}.590- \\
.000^{*}\end{array}$ & 1 \\
\hline
\end{tabular}

$* p<.05$

As shown in table 14, in terms of all factors determined that correlation coefficient was negative and statistically significant. Nevertheless, the strongest relationship between subjective norm and perceived behavioral control (.685-) and, weakest relationship is between attitude and perceived behavioral control (.411-).

\section{Conclusion and Recommendations}

Health professionals' intention towards voluntary blood donation is of critical importance as these intentions are characterized by high level of positive point of view and have the ability of influencing the whole population (Nwogoh et. al, 2013; Radunz et. al, 2010; Topbas et. al, 2005; Ahlawat et. al, 2013). For example, a survey performed in 811 health care professionals from Australia demonstrated that $96.2 \%$ of the participants look positive towards organ donation and that $90 \%$ wants to donate organ after death (Mark et. al, 2012). Another survey carried out in 482 health care professionals from Spain reported that $78 \%$ of the participants look positive towards organ donation (Rios et. al, 2008). In a similar survey from Qatar, 89\% of the doctors, 82\% of the nurses and $70.5 \%$ of the health technicians among 418 participants had positive point of view towards organ donation, however, $55 \%$ of the participants reported that they do not want to donate their organs (Alsaied et. al, 2012). Finally, a study from Turkey carried out with the participation of 309 health care professionals determined that $90 \%$ of the participants look positive towards organ donation but that only $22.98 \%$ possess he donor card (Demir et. al, 2011). The results of the 
present study as well as the other studies in the literature demonstrated that health care professionals have high intention to donate blood voluntarily $(\bar{X}=4.41)$. Nevertheless, health care professionals' high intention towards voluntary blood donation alone does not mean that donation would occur as adequate as intended. Therefore, contributions of future studies that will be performed in different population are required. Thus, the awareness is enhanced, and all parts of the population can be encouraged to support voluntary blood donation and to widen the existing donation pool. Within this context, producing strategies that keep the population away from misinformation and negative prejudices may be a good start.

It was reported that there are numerous variables that influence the intention of individuals who have the potential of donating blood voluntarily (Floden and Forsberg, 2009); however, there is no consensus about the power of these variables on intention. For example, a survey performed in 380 health care professionals from Barcelona determined that demographic variables do not have an impact on the attitude towards voluntary blood donation (Lomero et. al, 2015). A survey from Israel, which represented 2366 health care professionals, reported significant relationship between voluntary blood donation and age and marital status but not with gender (Cohen et. al, 2008). The results of another survey performed in 400 health care professionals from Germany revealed that voluntary blood donation behavior does not differ according to age, marital status or occupational status but differs according to gender (Radunz et. al, 2010). Finally, in Nigeria, the results of a survey performed in 163 health care professionals demonstrated that voluntary blood/organ donation behavior shows difference according to gender and age (Nwogoh et. al, 2013). The results of the present study reveal that health care professionals' intention to donate blood voluntarily shows difference according to gender, age, education level and monthly income but not to marital status. Therefore, taking the socio-demographic profiles differences into account during incentive campaigns for voluntary blood/organ donation is recommended.

Meanwhile, in 2010 III. Presented at the National Blood Centers and Transfusion Medical Congress, How Aware Are We? As a result of the survey conducted in the study titled A Survey Among Doctors on Blood Donation, 33 of 55 doctors who had not given blood before stated that they wanted to donate blood (Yaşar at el, 2010). this study was to evaluate the knowledge, behaviour and attitude of doctors working in various departments a hospital in Antalya of toward blood donation. A questionnaire with 20 questions was filled out by 100 doctors. Forty-five per 
cent of participants donated blood at least one time before, whereas $55 \%$ of them had never seriously considered becoming donor. Eighty-four per cent of nondonors were between 25-35 years old and $62 \%$ of them were female in this study. The half of nondonors wanted to donate only to their relatives in emergency situations. Surprisingly, seven refrained from blood donating due to the fear of catching an infectious disease during it.

Individuals can donate blood voluntarily if they are healthy enough. Current health status may either strengthen or limit the positive intentions towards voluntary donation to transform into behavior. For example; the behaviors related to voluntary blood donation were compared in a sample of 210 individuals which include spatients with organ failure and their relatives, patients with chronic diseases and healthy individuals. As a result, relatives of patients with organ failure were found to have a more positive attitude than healthy ones (Kaca et. al, 2009). As a result of a study representing 1484 health professionals in Brazil; 87\% of the healthy participants stated that they lean towards to voluntary blood donation, while this rate was reported to be $76 \%$ in patients with chronic disease (Araujo and Siqueira, 2016). Likewise, the results of the present study reveal that health care professionals with chronic illness have lower intention to donate blood voluntarily. Within this context, extension of regular health screening programs that cover the whole population and focusing on diagnosing the chronic diseases that have not detected yet may be beneficial. Thus, both the potential blood donors would be determined and the population's health status would be indirectly improved.

Assessment of intention towards a particular situation reflects mostly the loyalty of personal opinions (Sharp, 2013). When individuals are questioned about their intention towards the behaviors they have experienced for many times, they usually state that they would behave as was in the past. However, it is not possible to say that previous experiences influence all behaviors always in the same way. For example, a study carried out in 263 health care professionals from Spain determined no significant relationship between the attitudes towards voluntary blood donation and previous experiences (Rios et. al, 2005). On the contrary, the results of the present study indicate significant relationship between the health care professionals' previous experiences and their intention to donate blood voluntarily. 
Theory of Planned Behavior hypothesizes that relative burden of the intention-directing variables may show differences between individuals and between the populations (Fishbein and Ajzen, 2010). This hypothesis has been confirmed by the scientific studies, in which TPB was used. For example, in a cohort that continue smoking after attending a clinical incentive program for quitting smoking, perceived behavioral control was determined to be the strongest variable that predicts the intention to smoke (Norman et. al, 1999). In another study investigating the patients' intention to adhere with the prescribed medications, perceived behavioral control was the strongest variable that predicts the intention, while subjective norm was the weakest (Peleg et. al, 2017). Likewise, the results of the present study demonstrate that the strongest and the weakest variables that predict the health care professionals' intention to donate blood voluntarily are perceived behavioral control $(\beta=0.407)$ and subjective norm $(\beta=0.154)$, respectively. Our results indicate two critical conclusions: first, TPB can be used in health surveys as an effective method for assessing the intention. Second, subjective norm items in the questionnaires need to be enriched to enhance the theoretical power of TPB.

The study has some limitations. First of all, our results reflect only the health care professionals' intention to donate blood voluntarily because of absence of different populations in the study. Second, the results do not provide evidences representative of overall health care professionals as they are based on a limited sample size. Third, the present study has focused only on assessing the intention towards voluntary blood donation, but to what extend the intention turns into behavior has not been evaluated. The reason for this is the concern that time required for twophase researches might cause disconnection between intention and behavior. Finally, ready-to-use scales measure only the things the researcher wants to measure but not the further. In fact, scientific researches should include open-ended questions, which allow the participants to convey all of their opinions about a specific issue. However, open-ended items were not used in the present study as the questionnaire was performed in a study sample having limited time.

The most important step in encouraging blood donation is education and blood donation rates can only increase as the level of education increases. Since the healthcare professionals who are related to the subject, who have a certain level of education and are aware of the importance of blood donation, were considered as the target group in our study, blood donation rates were found to be higher compared to community-based studies. During the pandemic, which is 
experienced all over the world and our country was heavily affected, 2 million 370 thousand 912 units of blood were donated to the Red Crescent in 2020. Thanks to the collected immune plasmas, a significant support has been given to the fight against coronavirus. Blood donation is an important issue not only in pandemic and epidemic conditions, but also in natural disasters such as in earthquakes, floods, etc. and in such cases, the sensitivity of the society to this issue increases. Therefore, it is important to create strategic plans to increase the rate of blood donation. The barriers to donating blood will differ according to the cultural and sociological variables of each society. By determining them, it is a fact that there is a need for promotion programs that will increase the motivation for blood donation. The society should be enlightened about the importance, benefits and side effects of blood donation and misunderstandings should be prevented. In addition, blood donation should be encouraged with the support of the Red Crescent, relevant ministries, administrative staff, non-governmental organizations, opinion leaders of the society, intellectuals and the media.

\section{References}

Ahlawat, R. Kumar, V. Gupta, A.K. Sharma, R.K. and Minz, M. (2013). Attitude and knowledge of healthcare workers in critical areas towards deceased organ donation in a public sector hospital in India, The National Medical Journal of India, Vol. 26 (6).

Ajzen, I (2005). Attitudes, personality and behavior (2. Edition) Open University Press McGrawHill Education: England.

Çabuk,S. and Yağcı, M.İ.(Edt). (2014). MediaCat Kitapları, İstanbul.

Alsaied, O. Bener, A. Al-Mosalamani, Y. And Nour, B. (2012). Knowledge and attitudes of healthcare professionals toward organ donation and transplantation, Saudi Journal of Kidney Discases and Transplantation, Vol. 23 (6).

Amar, İ. And Yahia, O.(2020). Management of blood supply and demand during the COVID-19 pandemic in King Abdullah Hospital, Bisha, Saudi Arabia, Transfusion and Apheresis Science, 59, 102836. 
Araujo, C. and Siqueira, M. (2016). Brazilian healthcare professioanls: a study of attitudes toward organ donation, Transplantation Proceedings, Vol. 48 (10).

Argan, M.T. (2016). Examination on the framework of the theory of planned behavior of factors that affect blood donation behavior, Acıbadem University Journal of Health Science, Vol. $7(2)$.

Blood safety and availability (2018). World Health Organization blood donation statistics report, retrived 28 Aral1k 2019'da from website: https://www.who.int/en/news-room/factsheets/detail/blood-safety-and-availability.

Büyüköztürk, S. (2010). Data Analysis Handbook for Social Sciences (12th Edition), Pegem Academy: Ankara.

Cantürk, E. Ceylan, S. Akgün, U.Y. Kulular, A.Y. Kurtuluş, Y. Alnawajha, A. Şengelen, M. and Aslan, D. (2013). " Gönüllülük” kan merkezlerine başvuruda fark yaratır mı? Ankara’da seçilmiş kan merkezleri başvuruları üzerinden bir değerlendirme, Türkiye Halk Să̆lı̆̆l Dergisi, Vol. 11 (2).

Cevizci, S. Erginoz, E. and Yuceokur, A. (2010). Voluntary blood donation and factors affecting the behavior of giving blood, Turkey Clinics Cardiovasculer Sciences, Vol. 22 (1).

Cohen, J. Ben Ami, S. Ashkenazi, T. and Singer, P. (2008). Attitude of healthcare professionals to brain death: influence on the organ donation process, Clinical Transplantation, Vol. 22.

Demir, T. Selimen, D. Yildirim, M. and Kucuk, H.F. (2011). Knowledge and attitudes toward organ/tissue donation and transplantation among healthcare professionals working in organ transplantation or dialyses units, Transplantation Proceedings, Vol. 43 (5).

Field, A. (2009). Discovery Statistics Using SPSS (Third Edition). SAGE Publications: London.

Fishbein, M. Ajzen, I. (2010). Predicting and chancing behavior, Psychology Press Taylor \& Francis Group: United States of America. 
Floden, A. and Forsberg, A. (2009). A phenomenographic study of ICU-nurses' perceptions of and attitudes to organ donation and care of potential donors, Intensive and Critical Care Nursing, Vol. 25 (6).

Hablemitoğlu Ş., Y. Özkan and F. Yıldırım. (2010). Bir Fedakarlık Örneği Olarak Kan Bağışı, Aile ve Toplum, Y11: 11, Cilt: 5, Sayı: 20 Ocak-Şubat-Mart.

Kaca, G. Amado, S. Kikici, İ. Cilasin, S. Dag, E. Leylek, İ. And Sahin, Ö. (2009). Examination of attitudes towards organ donation within the framework of planned behavior theory, Turkish Journal of Psychology, Vol. 24 (64).

Korkmaz, S. and Sertoğlu, Ermeç, A. (2013) Genç tüketicilerin sürdürülebilir gıda tüketimi davranışının güven ve değerlere dayanan planlı davranış teorisi kapsamında tartışılması, H. U. İktisadi ve İdari Bilimler Fakültesi Dergisi, Cilt 31.

Lawson R. (Ed). (2010). Marketing theory a student text (2. Edition),SAGE Publications, London.

Lomero, M.M. Rasero, M.J. Fuentes, L. And Jaume, M. (2015). Knowledge and attitude of health personnel at the garraf health consortium regarding donation and transplantation, Transplantation Proceedings, Vol. 47 (8).

Marantidou, O. Loukopoulou, L. Zervou, E. Martinis, G. Egglezou, A. Fountouli, P. Dimoxenous, P. Parara, M. Gavalaki, M. and Maniatis, A. (2007). Factors that motivate and hinder blood donation in Greece, Transfusion Medicine, Vol. 17 (6).

Mark, C.H. Weiland, T.J. Neate, S.L. Hickey, B.B. and Jelinek, G.A. (2012). Personal attitudes and beliefs regarding organ and tissue donation: A cross sectional survey of Australian emergency department clinicians, Progress in Transplantation, Vol. 22 (3).

Glanz, K. Rimer, B.K. and Viswanath K.(eds.), Health Behavior and Health Education: Theory Research and Practice, San Francisco, Jossey-Bass.

Murphy, K.R. and Davidshoper, C.O. (2005). Psychological Testing Principles and Applications (Six Edition), Pearson Prentice Hall: USA. 
Norman, P. Conner, M. and Bell, R. (1999). The theory of planned behavior and smoking cessation, American Psychological Association Health Psychology, Vol. 18 (1).

Nwogoh, B. Aigberadion, U. and Nwannadi, A.I. (2013). Knowledge, attitude, and practice of voluntary blood donation among healthcare workers at the university of Benin Teaching Hospital, Benin City, Nigeria, Journal of Blood Transfusion, Article ID 797830.

Peleg, S. Vilchinsky, N. Fisher, W.A. Khaskia, and A. Mosseri, M. (2017). Personality makes a difference: attachment orientation moderates theory of planned behavior prediction of cardiac medication adherence, Journal of Personality, Vol. 85 (6).

Radunz, S. Hertel, S. Schmid, K.W. Heuer, M. Stommel, P. Frühauf, N.R. Saner F.H. Paul, A. and Kaieser G.M. (2010). Attitude of health care professionals to organ donation: the surveys among the staff of a Germany University Hospital, Transplantation Proceedings, Vol. 42 (1).

Rios, A. Conesa, C. Ramirez, P. Galindo, P.J. Martinez, L. Montaya, M.J Pons, J.A. Rodriguez, M.M. and Parrilla. P.(2005). Attitude toward deceased organ donation and transplantation among the workers in the surgical services in a hospital with a transplant program, Transplantation Proceedings, Vol. 37 (9).

Rios, A. Ramirez, P. Galindo, P.J. Sanchez, E. Martinez, A.L. and Parrilla, P. (2008). Primary health care personnel faced with cadaveric organ donation: a multicenter study in southeastern Spain, Clinical Transplantation, Vol. 22.

Sandborg, E. (2000). Getting People to Donate, Vox Sanguinis, 78. (Suppl. 2).

Sharp, B. (2013). Marketing theory, evidence, practice, Oxford University Press:Australia.

Topbas, M. Can, G. Can, M.A. and Ozgun, S. (2005). Outmoded attitudes toward organ donation among Turkish health care professionals, Transplantation Proceedings, Vol. 37 (5).

Voluntary blood donation in Turkey (2017). Turkish Red Crescent blood donation news, retrived 28 December 2019from website: https://www.kizilay.org.tr/Haber/HaberDetay/3290. 
Uzun, O. and Yigit, E. (2011). A Study on Mid-Level Hotel Managers on the Relationship between Orgutsel Stress and Organizational Loyalty. Eskisehir Osmangazi University, Journal of FEAS, Vol. 6 (1).

World Health Organization. (2010).Toward 100\% Voluntary Blood Donation: A global framework fo Action, retrived 18 Mart 2020 from website: http//www.who.int/world blood donor day//Melbourne Decleration WBDD09.pdf.

Yaflar K., Kadriye , F. Pehlivanoğlu, M., E., Işık, G., Çiçek, S., Gürsoy, M., Şimşek, S., Sandıkçı, H., Özkan, G., Şengöz, (2010), How Aware Are We? A Survey Among Doctors on Blood Donation, III. Ulusal Kan Merkezleri ve Transfüzyon Tibbi Kongresi, 24-28 Kasim Antalya. 